\title{
Flavonoid Nanoparticles: A Promising Approach for Cancer Therapy
}

\author{
Malgorzata Dobrzynska ${ }^{1}$, Marta Napierala ${ }^{2, *}$ a and Ewa Florek ${ }^{2, *}$ \\ 1 Department of Bromatology, Poznan University of Medical Sciences, 60-354 Poznan, Poland; \\ mdobrzynska@ump.edu.pl \\ 2 Laboratory of Environmental Research, Department of Toxicology, Poznan University of Medical Sciences, \\ 60-631 Poznan, Poland \\ * $\quad$ Correspondence: martan@ump.edu.pl (M.N.); eflorek@ump.edu.pl (E.F.); Tel.: +48-61-847-2081 (E.F.)
}

Received: 20 July 2020; Accepted: 31 August 2020; Published: 2 September 2020

\begin{abstract}
Flavonoids, a ubiquitous group of naturally occurring polyphenolic compounds, have recently gained importance as anticancer agents. Unfortunately, due to low solubility, absorption, and rapid metabolism of dietary flavonoids, their anticancer potential is not sufficient. Nanocarriers can improve the bioavailability of flavonoids. In this review we aimed to evaluate studies on the anticancer activity of flavonoid nanoparticles. A review of English language articles published until 30 June 2020 was conducted, using PubMed (including MEDLINE), CINAHL Plus, Cochrane, and Web of Science data. Most studies determining the anticancer properties of flavonoid nanoparticles are preclinical. The potential anticancer activity focuses mainly on MCF-7 breast cancer cells, A549 lung cancer cells, HepG2 liver cancer cells, and melanoma cells. The flavonoid nanoparticles can also support the anti-tumour effect of drugs used in cancer therapy by enhancing the anti-tumour effect or reducing the systemic toxicity of drugs.
\end{abstract}

Keywords: flavonoid nanoparticles; flavonoid loaded nanobiomaterials; cancer; cancer treatments; anticancer activity

\section{Introduction}

Flavonoids are the most common and widely distributed group of plant compounds, occurring virtually in all plant parts. This group can be divided into several subfamilies such as flavones, flavanols, flavanones, flavonols, and isoflavones [1]. As a dietary component, flavonoids are thought to have beneficial effects on human health [2]. Their health-promoting properties are associated with antioxidant [3], anti-inflammatory [4], and anticancer properties [5]. Nowadays attention is drawn to the anticancer activity of flavonoids. Many studies have documented flavonoids, for example, epigallocatechin-3-gallate, quercetin, genistein, apigenin, naringenin, silibinin, and kaempferol, to be effective against various types of cancer. Unfortunately, due to low solubility [2], poor absorption [6], and rapid metabolism [7], use of flavonoids in cancer treatment is not satisfactory. In this regard, modern nanotechnology may be used. Nanocarriers can improve the bioavailability of flavonoids [1]. In vitro and in vivo studies have shown potential anticancer activity of flavonoid nanoparticles against A549 lung cancer cells, B16F10 melanoma cells, MCF-7 breast cancer cells, HepG2 liver cancer cells or CT26 colorectal cancer cells [8-12]. There are several different types of flavonoid nanocarriers currently used in cancer therapy. These include polymeric nanoparticles [13], nanocapsules [14], metallic nanoparticles (gold) [15] or solid lipid nanocarriers [16].

This review aims to evaluate studies on the anticancer activity of flavonoid nanoparticles. A review of English language articles published until 30 June 2020 was conducted, using PubMed (including MEDLINE), CINAHL Plus (Cumulative Index to Nursing and Allied Health Literature), Cochrane, 
and Web of Science data. The literature search was performed using MESH terms (Medical Subject Headings) and other relevant keywords. The key search terms were "flavonoid nanoparticles", "flavonoid loaded nanobiomaterials", "flavonoid nanoparticles and cancer"; "flavonoid nanoparticles and cancer treatments", and "flavonoid nanoparticles and anticancer activity".

\section{Epigallocatechin-3-gallate (EGCG)}

Epigallocatechin-3-gallate is found in the leaves of green tea and its role in the treatment of cancer has been studied intensively $[17,18]$. The antioxidant effect of EGCG is limited by poor absorption after oral administration, unfavourable pharmacokinetics and biodistribution, low accumulation in the tissues, or low targeting efficacy [19]. It is worth noting that some studies suggest high doses of EGCG can induce toxicity in the liver [20]. However, EGCG nanoparticles induced high tumour growth inhibition in the case of prostate, breast, liver, gastric, bladder, and melanoma cancers. The concept of nanotherapy in cancer was introduced by Siddiqui et al. [21]. The polylactic acid-polyethylene glycol (PLA-PEG) with encapsulated EGCG nanoparticles were used in this study [21]. It was observed that these nanoparticles were more than 10 -fold effective against $22 \mathrm{Rr} 1$ prostate cancer cells than free EGCG [21]. The use of PLA-PEG nanoparticles could be useful to limit the toxicity and enhance the bioavailability of EGCG. Injection EGCG PLA-PEG nanoparticles minimize carrier-induced undesirable cytotoxicity and improve the pharmacokinetic and pharmacodynamic properties of this flavonoid [21]. These positive results have initiated studies of other flavonoids and nanoparticles which may have potential effect in cancer treatment. Another example is EGCG-conjugated gold nanoparticles. The beneficial effect of gold nanoparticles in cancer treatment is associated with the small size, non-toxicity, and non-immunogenicity, which cause these nanoparticles to be able to pass natural barriers in human body and control the release of drugs in different locations. Furthermore, gold nanoparticles are mainly used for imaging and radiation sensitization [22]. In study by Hsieh et al., EGCG was physically attached to the surface of nanogold particles. In mice subcutaneously implanted with MBT-2 murine bladder tumour cells, an inhibition of growing cancer cells took place by means of cell apoptosis [23,24]. Following studies about EGCG gold-nanoparticles inserted into the tumour also confirmed a significant reduction of tumour growth in PC-3 prostate cells and B16F10 melanoma cells [25,26]. The Rocha study showed that the EGCG incorporated with a carbohydrate matrix of gum arabic and maltodextrin carbohydrate matrix induced apoptosis in Du145 prostate cancer cells [27]. The use of a carbohydrate matrix of arabic gum and maltodextrin nanoparticles contributes to preserve antioxidant properties and improves the bioavailability of flavonoids [28].

In the Siddiqui et al. study, EGCG-encapsulated chitosan induced apoptosis in Mel928 melanoma cells. Chitosan nanoparticles are characterized by mucoadhesive properties. After oral administration, flavonoids encapsulated in chitosan nanoparticles adhere to the gastrointestinal tract a for longer time, which cause a longer release of the drug [29]. Further research was carried out on prostate cancer cells. Oral administration of chitosan-based EGCG significantly inhibited prostate cancer cell growth in a xenograft model compared to free EGCG [30]. In the in vitro model, the EGCG encapsulated chitosan-coated nanoliposomes (CALIPPO) and EGCG loaded folic acid-poly(ethylene glycol)-FA-PEG nanoparticles induced apoptosis and inhibited MCF-7 breast cancer cells [8,31]. EGCG has been extensively studied as a prospective anti-tumour drug in the treatment of melanoma cancer. The epigallocatechin-3-gallate-loaded fucose-chitosan/polyethylene glycol-chitosan/gelatin nanoparticles induced apoptosis in MKN45-Luc gastric cancer cells and reduced vascular endothelial growth factor protein expression [32].

Other nanoparticles that improve the anticancer effect of EGCG are nanoethosomes and chitin-loaded honokiol. A study by Liao et al. showed that transdermal delivery docetaxel loaded in EGCG-nanoethosomes reduced the tumour volume. The nanoethosomes allow transdermal delivery of flavonoids to melanoma cancer cells [33]. The Tang et al. study showed that EGCG nanoparticles (chitin-laden honokiol) inhibited the proliferation of HepG2 cancer cell cells by inhibiting cells in the 
G2/M phase and reducing the potential of the mitochondrial membrane [34]. The anticancer effect of epigallocatechin-3-gallate nanoparticles is represented in Table 1.

Table 1. Anticancer effect of epigallocatechin-3-gallate (EGCG) nanoparticles in in vitro and in vivo studies.

\begin{tabular}{|c|c|c|c|}
\hline Nanomaterial Type & Cancer Type/Effect & Study Type & Reference \\
\hline PLA-PEG & $\begin{array}{l}\text { PROSTATE CARCINOMA } \\
\text { over 10-fold dose advantage } \\
\text { for exerting its proapoptotic } \\
\text { and angiogenesis inhibitory } \\
\text { effects on } 22 \mathrm{Rr} 1 \text { cells }\end{array}$ & $\begin{array}{l}\text { Animal model } \\
\text { (mice) }\end{array}$ & $\begin{array}{l}\text { Siddiqui I. A. et al., } \\
2009 \text { [21] }\end{array}$ \\
\hline \multirow{4}{*}{ Gold } & $\begin{array}{l}\text { BLADDER TUMOUR } \\
\text { inhibition of tumour growth } \\
\text { (MBT-2 cells) }\end{array}$ & $\begin{array}{l}\text { Animal model } \\
\text { (mice) }\end{array}$ & $\begin{array}{l}\text { Hsieh D. S. et al., } \\
\text { 2011 [23] }\end{array}$ \\
\hline & $\begin{array}{l}\text { PROSTATE CARCINOMA } \\
\text { inhibition of the tumour } \\
\text { growth (PC-3 cells) }\end{array}$ & $\begin{array}{l}\text { Animal model } \\
\text { (mice) }\end{array}$ & $\begin{array}{l}\text { Shukla R. et al., } \\
2012 \text { [25] }\end{array}$ \\
\hline & $\begin{array}{l}\text { BLADDER TUMOUR } \\
\text { inhibition of tumour growth } \\
\text { (MBT-2 cells) }\end{array}$ & $\begin{array}{l}\text { Animal model } \\
\text { (mice) }\end{array}$ & $\begin{array}{l}\text { Hsieh D. S. et al., } \\
2012 \text { [24] }\end{array}$ \\
\hline & $\begin{array}{l}\text { MELANOMA } \\
\text { inhibition of tumour growth } \\
\text { (B16F10 cells) }\end{array}$ & $\begin{array}{l}\text { Animal model } \\
\text { (mice) }\end{array}$ & $\begin{array}{l}\text { Chen C. C. et al., } \\
2014 \text { [26] }\end{array}$ \\
\hline $\begin{array}{l}\text { Carbohydrate matrix of } \\
\text { gum-arabic and maltodextrin }\end{array}$ & $\begin{array}{l}\text { PROSTATE CARCINOMA } \\
\text { induction of apoptosis, } \\
\text { reduction of the cell viability } \\
\text { (Du145 cells) }\end{array}$ & In vitro model & $\begin{array}{l}\text { Rocha S. et al.,2011 } \\
\text { [27] }\end{array}$ \\
\hline \multirow{2}{*}{ Chitosan } & $\begin{array}{c}\text { MELANOMA } \\
\text { induction of apoptosis Mel } \\
928 \text { cells }\end{array}$ & $\begin{array}{l}\text { Animal model } \\
\text { (mice) }\end{array}$ & $\begin{array}{l}\text { Siddiqui I. A. et al., } \\
2014 \text { [29] }\end{array}$ \\
\hline & $\begin{array}{l}\text { PROSTATE CARCINOMA } \\
\text { inhibitory effect on cancer cells } \\
\text { (22Rr1 cells) }\end{array}$ & $\begin{array}{l}\text { Animal model } \\
\quad(\text { mice })\end{array}$ & $\begin{array}{l}\text { Khan N. et al., } 2014 \\
\text { [30] }\end{array}$ \\
\hline $\begin{array}{c}\text { CSLIPO } \\
\text { chitosan-coated nanoliposomes }\end{array}$ & $\begin{array}{l}\text { BREAST CANCER } \\
\text { anti-proliferative and } \\
\text { proapoptotic effect } \\
\text { (MCF-7 cells) }\end{array}$ & In vitro model & $\begin{array}{l}\text { de Pace R. C. C. et } \\
\text { al., } 2013 \text { [8] }\end{array}$ \\
\hline $\begin{array}{c}\text { FA-PEG } \\
\text { folic acid-poly(ethylene glycol) }\end{array}$ & $\begin{array}{c}\text { BREAST CANCER } \\
\text { inhibition of MCF-7 cell } \\
\text { proliferation }\end{array}$ & In vitro model & $\begin{array}{l}\text { Zeng L. et al., } 2017 \\
\text { [31] }\end{array}$ \\
\hline $\begin{array}{c}\text { FU-PEG } \\
\text { fucose-chitosan/polyethylene } \\
\text { glycol-chitosan/gelatin }\end{array}$ & $\begin{array}{l}\text { GASTRIC CANCER inhibition } \\
\text { of tumour growth } \\
\text { (MKN45-Luc cells) }\end{array}$ & $\begin{array}{l}\text { Animal model } \\
\text { (mice) }\end{array}$ & $\begin{array}{l}\text { Lin Y. H. et al., } 2015 \\
\text { [32] }\end{array}$ \\
\hline EGCG-nanoethosomes & $\begin{array}{c}\text { MELANOMA } \\
\text { inhibition of tumour growth } \\
\text { (A375 human melanoma cells) }\end{array}$ & $\begin{array}{l}\text { Animal model } \\
\text { (mice) }\end{array}$ & $\begin{array}{l}\text { Liao B. et al.,2016 } \\
\text { [33] }\end{array}$ \\
\hline Chitin loaded-honokiol & $\begin{array}{l}\text { LIVER CANCER } \\
\text { inhibited more cells in the } \\
\text { G2/M phase and decreased } \\
\text { mitochondrial membrane } \\
\text { potential (HepG2 cells) }\end{array}$ & $\begin{array}{l}\text { Animal model } \\
\text { (mice) }\end{array}$ & $\begin{array}{l}\text { Tang P. et al., } 2018 \\
\text { [34] }\end{array}$ \\
\hline
\end{tabular}

\section{Quercetin}

Quercetin (QT) is one of the most abundant flavonoids found in vegetables. It causes cell cycle arrest in proliferating lymphoid cells and inhibits growth and formation of several tumour cell lines in vitro [35]. Due to low water solubility and poor absorption of this flavonoid, numerous 
in vivo and in vitro studies have been conducted on nanoparticles to improve physicochemical properties. In vivo quercetin nanoparticles have a potent anticancer effect on A549 lung cancer cells [9,36], A2780S ovarian cancer cells [24,25], B16F10 melanoma cells [26,27], MCF-7, T1 breast cancer cells [10,36-38], CT26 colorectal cancer cells [11], U87 neuroglioma cells [39], C6 glioma cells [40], U14 cervical cancer cells [41], and hepatocellular cancer cells [36,42-46].

The most commonly used nanoparticles with quercetin are PEG, poly(lactic co-glycolic acid) nanoparticles (PLGA) and PLA. It has been reported that PEG nanoparticles prolong the circulation time of quercetin in the bloodstream and increase its solubility and stability [47]. The Tan et al. study showed that the PEG-derivatized phosphatidylethanolamine nanomicelles improved the anticancer activity of quercetin. It has been observed that these nanoparticles were more effective against A549 lung cancer cells than free quercetin [9]. Another study by Xing et al. showed that de-PEGylated nanoparticles based on triphenylphosphine-quercetin (TPP-PEG) were more effective therapeutic agents compared to pure quercetin in A459, MCF-7, and HepG2 cancer cells [36]. The anticancer activity of quercetin loaded in PEG was observed in the study of Dora et al. The results indicated that oral administration of nanosized PEG emulsion containing quercetin had cytotoxicity activity against B16F10 melanoma cells [48]. Similarly, by using quercetin loaded PEG-liposomal nanoparticles, inhibition of angiogenesis of ovarian cancer was achieved [49]. The Zhao et al. study showed that the 1,2-distearoyl-sn-glycero-3-phosphoethanolamine- $N$-methoxy(polyethylene glycol) (DSPE-MPEG) is a good adjuvant nanocarrier for anticancer drug delivery [50]. A few studies on the treatment of hepatocellular cancer with PLGA-loaded quercetin nanoparticles have been shown. In the Ghosh et al. study, the PLGA nanoparticles loaded in quercetin completely protected the mitochondrial membrane of the liver against cancer induced by diethylnitrosamine [42]. After oral administration, PLGA nanoparticles encapsulated with quercetin and tamoxifen (TMX) controlled tumour angiogenesis in MCF-7 breast cancer cells [10]. The Panday et al. study has proven that oral administration rutin-loaded PLGA nanoparticles of quercetin improved hepatic parameters and increased superior inflammatory markers [45]. Quercetin encapsulated in monomethoxy poly(ethylene glycol)-poly( $\varepsilon$-caprolactone) (MPEG-PCL) nanoparticles inhibited ovarian tumour growth by the mitochondrial apoptotic pathway [51,52]. Moreover, the anticancer efficacy of GeluPearl comprising of Precirol ATO 5 lipid (GPSLN) nanoparticles loaded with quercetin against B16F10 melanoma cells was proved [53]. In another study (Mandal et al.), inhibition of development of hepatocellular carcinoma by PLA nanoparticles has been shown [43]. The gold-quercetin in PLA nanoparticles inactivated the caspase/Cyto-c pathway in hepatocellular cells [44]. The da Luz et al. study has shown that poly-lactic acid nanoparticles have an anticancer effect on A549 lung cancer cells [54]. In the Li et al. study, quercetin-loaded soybean phosphatidylcholine-cholesterol (SPC-CHOL) inhibited U14 cervical cancer cells [41]. The anticancer activity of quercetin against breast cancer was observed by using PVP [38]. To improve the effect of quercetin, gold-PLA nanoparticles were also used $[39,44,55]$. The in vivo studies have confirmed that quercetin nanoparticles have potential in cancer treatment (Table 2). 
Table 2. Anticancer effect of quercetin (QT) nanoparticles in in vivo studies.

\begin{tabular}{|c|c|c|c|}
\hline Nanomaterial Type & Cancer Type/Effect & Study Type & Reference \\
\hline $\begin{array}{c}\text { PEG } \\
\text { poly(ethylene glycol) }\end{array}$ & $\begin{array}{c}\text { MELANOMA } \\
\text { inhibition of tumour growth } \\
\text { (B16F10 melanoma cells) }\end{array}$ & Animal model (mice) & $\begin{array}{l}\text { Dora C. L. et al., } \\
2016 \text { [48] }\end{array}$ \\
\hline $\begin{array}{c}\text { PEG- } \\
\text { phosphatidylethanolamine }\end{array}$ & $\begin{array}{l}\text { LUNG CANCER } \\
\text { anticancer activity in the A549 } \\
\text { lung cancer cells }\end{array}$ & Animal model (mice) & $\begin{array}{c}\text { Tan B. J. et al., } 2012 \\
\text { [9] }\end{array}$ \\
\hline $\begin{array}{l}\text { PEG-liposomal } \\
\text { polyethylene glycol-liposomal }\end{array}$ & $\begin{array}{l}\text { OVARIAN CANCER induction } \\
\text { of apoptosis and inhibition of } \\
\text { angiogenesis }\end{array}$ & Animal model (mice) & $\begin{array}{c}\text { Long Q. et al., } 2013 \\
\text { [49] }\end{array}$ \\
\hline $\begin{array}{c}\text { TPP-PEG } \\
\text { Triphenylphosphine } \\
\text { quercetin nanoparticles } \\
\text { poly(ethylene glycol) }\end{array}$ & $\begin{array}{c}\text { MITOCHONDRIA-TARGETED } \\
\text { TUMOUR THERAPY } \\
\text { (MCF-7, A459 and HepG2 cells) }\end{array}$ & Animal model (mice) & $\begin{array}{c}\text { Xing L. et al., } 2017 \\
\text { [36] }\end{array}$ \\
\hline $\begin{array}{c}\text { DSPE-MPEG } \\
\text { 1,2-distearoyl-sn-glycero- } \\
\text { 3-phosphoethanolamine- } \\
N \text {-methoxy(polyethylene } \\
\text { glycol) }\end{array}$ & $\begin{array}{l}\text { PROSTATE CANCER apoptosis } \\
\text { induction of human } \\
\text { androgen-independent PC-3 } \\
\text { cells increased drug } \\
\text { accumulation at the tumour site } \\
\text { and superior anticancer activity }\end{array}$ & Animal model (mice) & $\begin{array}{c}\text { Zhao J. et al., } 2016 \\
\text { [50] }\end{array}$ \\
\hline $\begin{array}{l}\text { PLGA (poly(lactic co-glycolic } \\
\text { acid) nanoparticles }\end{array}$ & $\begin{array}{l}\text { HEPATOCELLULAR } \\
\text { CARCINOMA } \\
\text { protection of the mitochondrial } \\
\text { membrane of the liver from } \\
\text { carcinoma mediated prevention } \\
\text { of the cytochrome C expression } \\
\text { in the liver }\end{array}$ & Animal model (rats) & $\begin{array}{l}\text { Ghosh A. et al., } \\
2012 \text { [42] }\end{array}$ \\
\hline $\begin{array}{c}\text { PLGA-TMX } \\
\text { (poly(lactic co-glycolic acid) } \\
\text { tamoxifen }\end{array}$ & $\begin{array}{l}\text { BREAST CANCER } \\
\text { oral administration efficiently } \\
\text { controlled the tumour } \\
\text { angiogenesis, normalized levels } \\
\text { of the markers (MMP-2 and } \\
\text { MMP-9) in MCF-7 cells }\end{array}$ & Animal model (rats) & $\begin{array}{l}\text { Jain A. K. et al., } \\
2013 \text { [10] }\end{array}$ \\
\hline $\begin{array}{l}\text { RT-PLGA (poly(lactic } \\
\text { co-glycolic acid) nanoparticles } \\
\text { of rutin }\end{array}$ & $\begin{array}{c}\text { HEPATOCELLULAR } \\
\text { CARCINOMA } \\
\text { reduced incidence of hepatic } \\
\text { nodules, necrosis formation, } \\
\text { infiltration of inflammatory cells, } \\
\text { blood vessel inflammation and } \\
\text { cell swelling }\end{array}$ & Animal model (rats) & $\begin{array}{l}\text { Pandey P. et al., } \\
\quad 2018 \text { [45] }\end{array}$ \\
\hline $\begin{array}{c}\text { QT-loaded PLGA-TPGS } \\
\text { (QPTN) } \\
\text { poly-(dl-lactic-co-glycolic } \\
\text { acid)-D- } \alpha \text {-tocopherol } \\
\text { polyethylene glycol succinate }\end{array}$ & $\begin{array}{l}\text { LIVER CANCER suppression of } \\
\text { the tumour growth HepG } 2 \text { and } \\
\text { HCa-F cells }\end{array}$ & Animal model (mice) & $\begin{array}{c}\text { Guan X. et al., } 2016 \\
\text { [46] }\end{array}$ \\
\hline \multirow{2}{*}{$\begin{array}{c}\text { MPEG-PCL } \\
\text { monomethoxy poly(ethylene } \\
\text { glycol)-poly( } \varepsilon \text {-caprolactone) }\end{array}$} & $\begin{array}{l}\text { OVARIAN CANCER inhibition } \\
\text { of the growth of A2780S ovarian } \\
\text { cancer cells through the } \\
\text { mitochondrial apoptotic } \\
\text { pathway }\end{array}$ & Animal model (mice) & $\begin{array}{c}\text { Gao X. et al., } 2012 \\
{[51]}\end{array}$ \\
\hline & $\begin{array}{c}\text { COLORECTAL CANCER } \\
\text { improved apoptosis induction } \\
\text { and inhibition of cell growth in } \\
\text { CT26 cells }\end{array}$ & Animal model (mice) & $\begin{array}{l}\text { Xu G. et al., } 2015 \\
\text { [11] }\end{array}$ \\
\hline $\begin{array}{c}\text { GPSLN } \\
\text { GeluPearl comprising of } \\
\text { Precirol ATO } 5 \text { nanoparticles }\end{array}$ & $\begin{array}{l}\text { MELANOMA } \\
\text { reduced lung colonization and } \\
\text { enhanced anti-metastatic activity } \\
\text { against B16F10 melanoma cells }\end{array}$ & Animal model (mice) & $\begin{array}{l}\text { Jain A. S. et al., } \\
2013 \text { [53] }\end{array}$ \\
\hline
\end{tabular}


Table 2. Cont.

\begin{tabular}{|c|c|c|c|}
\hline Nanomaterial Type & Cancer Type/Effect & Study Type & Reference \\
\hline $\begin{array}{c}\text { PLA } \\
\text { poly (dl-lactide-co-glycolide) }\end{array}$ & $\begin{array}{l}\text { HEPATOCELLULAR } \\
\text { CARCINOMA } \\
\text { restricted development of } \\
\text { hepatocarcinogenesis }\end{array}$ & Animal model (rats) & $\begin{array}{c}\text { Mandal A. K. et al., } \\
2014 \text { [43] }\end{array}$ \\
\hline $\begin{array}{c}\text { MPEG-PLA } \\
\text { methoxy poly(ethylene } \\
\text { glycol)-poly(lactide) }\end{array}$ & $\begin{array}{c}\text { BREAST CANCER } \\
\text { inhibition of tumour growth } \\
\text { (mammary cancer T1 cells) }\end{array}$ & Animal model (mice) & $\begin{array}{l}\text { Sharma G. et al., } \\
2015 \text { [52] }\end{array}$ \\
\hline \multirow{3}{*}{$\begin{array}{c}\text { Gold-PLA } \\
\text { gold-quercetin into poly } \\
\text { (dl-lactide-co-glycolide) } \\
\text { nanoparticles }\end{array}$} & $\begin{array}{l}\text { CERVICAL CANCER induced } \\
\text { apoptosis, autophagy and } \\
\text { anti-proliferation via Janus } \\
\text { kinase } 2 \text { suppression }\end{array}$ & Animal model (mice) & $\begin{array}{l}\text { Luo C. L. et al., } \\
\qquad 2016 \text { [55] }\end{array}$ \\
\hline & $\begin{array}{c}\text { NEUROGLIOMA } \\
\text { induced autophagy and } \\
\text { apoptosis in human } \\
\text { neuroglioma U87 cells through } \\
\text { activation LC3/ERK/Caspase-3 } \\
\text { and suppression of AKT/mTOR } \\
\text { signaling pathway }\end{array}$ & Animal model (mice) & $\begin{array}{l}\text { Lou M. et al., } 2016 \\
\text { [39] }\end{array}$ \\
\hline & $\begin{array}{c}\text { HEPATOCELLULAR } \\
\text { CARCINOMA } \\
\text { inactivation of caspase/Cyto-c } \\
\text { pathway, suppression of } \\
\text { AP-2 } \beta / \text { telomerase reverse } \\
\text { transcriptase hTERT, inhibition } \\
\text { of NF-kB/cyclooxygenase } 2 \\
\text { COX-2 and Akt/ERK1/2 } \\
\text { signaling pathways }\end{array}$ & Animal model (mice) & $\begin{array}{l}\text { Ren K. W. et al., } \\
2017 \text { [44] }\end{array}$ \\
\hline $\begin{array}{l}\text { Freeze-dried polymeric } \\
\text { micelles }\end{array}$ & $\begin{array}{c}\text { GLIOMA } \\
\text { cytotoxic effect on C6 glioma } \\
\text { cells }\end{array}$ & Animal model (mice) & $\begin{array}{c}\text { Wang G. et al., } 2016 \\
{[40]}\end{array}$ \\
\hline $\begin{array}{c}\text { SPC-CHOL } \\
\text { soybean } \\
\text { phosphatidylcholine-cholesterol }\end{array}$ & $\begin{array}{c}\text { CERVICAL CANCER } \\
\text { in vitro anti-tumour efficacy to } \\
\text { Hela cells in vivo inhibition } \\
\text { effect on U14 cells }\end{array}$ & Animal model (mice) & Li J. et al., 2017 [41] \\
\hline $\begin{array}{c}\text { PVP } \\
\text { poly (vinyl pyrrolidone) }\end{array}$ & $\begin{array}{l}\text { BREAST CANCER antioxidative } \\
\text { activity and efficient } \\
\text { photothermal killing effect to } \\
\text { cancer } 4 \text { T1 cells }\end{array}$ & Animal model (mice) & $\begin{array}{l}\text { Tang S. H. et al., } \\
2019 \text { [38] }\end{array}$ \\
\hline
\end{tabular}

\section{Genistein}

Genistein is an isoflavonoid found in a number of plants including soybeans, fava beans, and lupins [56]. Some studies have shown beneficial effects of genistein nanoparticles against several cancer lines. Genistein has poor water solubility, rapid metabolism, and low oral bioavailability, which limit the clinical application of this flavonoid [57]. Genistein loaded TPGS-b-PCL (d- $\alpha$-tocopheryl polyethylene glycol 1000 succinate-poly( $\varepsilon$-caprolactone)) inhibited HeLa cervical tumour cells growth and had a higher level of cytotoxicity compared to genistein-loaded PCL nanoparticles [58], whereas genistein-loaded M-PLGA-TPGS (poly(d,l-lactide-co-glycolide)-d- $\alpha$-tocopheryl polyethylene glycol 1000 succinate) had a linear apoptotic effect against HepG2 liver cancer cells [12]. Unfortunately, the improvement in the bioavailability of genistein resulting from the use of nanoparticles is associated with high cytotoxicity in normal cells. Further in vitro studies focused on anticancer activity (apoptosis and autophagy of cancer cells) in colon cancer HT29 cells with genistein-loaded PEGylated silica hybrid nanomaterials and lung cancer A549 cells with genistein-miRNA-29b-loaded hybrid nanoparticles-GMLHN, as well as hematopoietic cancer cells with genistein-carboxymethylated chitosan nanoparticles-Fe3O4-CMC [59-61]. Despite low water solubility, low bioavailability, and instability of pure genistein, the genistein-loaded nanoparticles described in the presented studies 
have made it possible to use them in anticancer treatment [62]. Studies on the anticancer activity of genistein nanoparticles are presented in Table 3.

Table 3. Anticancer effect of genistein nanoparticles in in vitro and in vivo studies.

\begin{tabular}{|c|c|c|c|}
\hline Nanomaterial Type & Cancer Type/Effect & Study Type & Reference \\
\hline TPGS-b-PCL & $\begin{array}{c}\text { CERVICAL CANCER } \\
\text { inhibition of tumour growth } \\
\text { (HeLa cells) }\end{array}$ & $\begin{array}{l}\text { Animal model } \\
\text { (mice) }\end{array}$ & $\begin{array}{l}\text { Zhang H. et al., } \\
2015 \text { [58] }\end{array}$ \\
\hline M-PLGA-TPGS & $\begin{array}{c}\text { LIVER CANCER } \\
\text { apoptotic effect against HepG2 cells }\end{array}$ & $\begin{array}{l}\text { Animal model } \\
\text { (mice) }\end{array}$ & $\begin{array}{l}\text { Wu B. et al., } 2016 \\
\text { [12] }\end{array}$ \\
\hline $\begin{array}{l}\text { PEGylated silica hybrid } \\
\text { nanomaterials }\end{array}$ & $\begin{array}{c}\text { COLON CANCER } \\
\text { HT29 cells modulation of endogenous } \\
\text { antioxidant enzymes and } \mathrm{H}_{2} \mathrm{O}_{2} \\
\text { production, which simultaneously } \\
\text { activated apoptosis and autophagy }\end{array}$ & In vitro model & $\begin{array}{c}\text { Pool, H et al., } 2018 \\
\text { [59] }\end{array}$ \\
\hline $\begin{array}{c}\text { GMLHN } \\
\text { (Genistein-miRNA- } \\
\text { 29b-loaded hybrid } \\
\text { nanoparticles) }\end{array}$ & $\begin{array}{c}\text { LUNG CANCER } \\
\text { Phosphorylated protein kinase, strain } \\
\text { AK, Thymoma (Phosphorylated } \\
\text { protein kinase B) (pAKT), } \\
\text { Phosphorylated phosphoinositide } \\
\text { 3-kinase (p-PI3K), DNA } \\
\text { (cytosine-5-)-methyltransferase } 3 \text { beta } \\
\text { (DNMT3B) and Myeloid Cell } \\
\text { Leukemia Sequence 1 (MCL 1) } \\
\text { efficiently downregulated, } \\
\text { anti-proliferative effect non-small cell } \\
\text { lung cancer A549 cells }\end{array}$ & In vitro model & $\begin{array}{l}\text { Sacko K. et al., } 2019 \\
\text { [61] }\end{array}$ \\
\hline $\begin{array}{l}\mathrm{Fe}_{3} \mathrm{O}_{4}-\mathrm{CMC} \\
\text { (carboxymethylated } \\
\text { chitosan) }\end{array}$ & $\begin{array}{l}\text { HEMATOPOIETIC CANCER } \\
\text { significant growth inhibition of } \\
\text { hematopoietic cancer cells }\end{array}$ & In vitro model & $\begin{array}{c}\text { Ghasemi } \\
\text { Goorbandi R. et al., } \\
2020 \text { [62] }\end{array}$ \\
\hline
\end{tabular}

\section{Silibinin}

Silibinin is found in the seeds of milk thistle [63]. Studies show that silibinin has an antineoplastic potential against many cancers by promoting the cell-cycle and inhibiting proliferation [64]. However, due to its hydrophobic structure, it has poor water solubility and permeability across intestinal epithelial cells. To improve the effect of silibinin, nanoparticles, i.e., PEG, polyvinyl alcohol (PVA), and poly- $N$-(2-hydroxypropyl) methacrylamide (pHPMA)-coated wheat germ agglutinin-modified lipid-polymer hybrid nanoparticles have been used [65]. The study of $\mathrm{Xu}$ et al. on silibinin nanoparticles described their effect on cancer cells and the blocking of metastasis of breast cancer. These silibinin-loaded lipid nanoparticles (SLNs) containing TPGS and phosphatidylcholine were designed and prepared by a thin-film hydration method [66]. In another study (Gohulkumar et al.), silibinin encapsulated in PVA-Eudragit nanoparticles showed anticancer efficacy in oral carcinoma cells [67]. Another study showed that silibinin encapsulated in PEG nanoparticles had a cytotoxic effect on breast cancer (MCF 10A) in vitro [68]. Free silibinin has low solubility and inadequate dissolution, which cause low oral bioavailability. The Sahibzada et al. study shows two methods for manufacturing nanoparticles of silibinin (APSP — anti-solvent precipitation with a syringe pump and EPN-evaporative precipitation of nanosuspension), which increase its solubility, making this flavonoid a potential oral drug in cancer therapy [69]. Huo et al. showed that the combination therapy of silibinin and paclitaxel (PTX) loaded in dextran-deoxycholic acid (Dex-DOCA) nanoparticles effectively accumulate in tumour sites by passive targeting and inhibit tumour growth through an enhanced intratumoural penetration in mice [70]. Changes in the tumour microenvironment were observed in another study where silibinin and IPI-549 nanoparticles (AEAA-PEG-PCL-aminoethyl anisamide-polyethylene glycol-polycaprolactone) inhibited 4T1 breast cancer cells [71]. It is also worth noting that silibinin demonstrates an anti-metastasis effect. Research on the poly-N-(2-hydroxypropyl) 
methacrylamide (pHPMA)-coated wheat germ agglutinin-modified lipid-polymer hybrid nanoparticles, co-loaded with silibinin and cryptotanshinone $(\mathrm{S} / \mathrm{C}-\mathrm{pW})$, showed inhibition of tumour growth in $4 \mathrm{~T} 1$ tumour-bearing mice and presented anti-metastasis activity in the lung [72]. In vitro and in vivo studies concerning the potential anticancer activity of silibinin nanoparticles are presented in Table 4 .

Table 4. Anticancer effect of silibinin nanoparticles in in vitro and in vivo studies.

\begin{tabular}{cccc}
\hline Nanomaterial Type & Cancer Type/Effect & Study Type & Reference \\
PVA-Eudragit & $\begin{array}{c}\text { ORAL CARCINOMA } \\
\text { inhibition of apoptosis } \\
\text { KB cells }\end{array}$ & In vitro model & $\begin{array}{c}\text { Gohulkumar M. et al., } \\
\text { 2014 [67] }\end{array}$ \\
\hline PEG & $\begin{array}{c}\text { BREAST CANCER } \\
\text { cytotoxic effect on MCF } \\
\text { 10A }\end{array}$ & In vitro model & $\begin{array}{c}\text { Sajjadiyan S. Z. et al., } \\
\text { 2016 [68] }\end{array}$ \\
\hline AEAA-PEG-PCL & $\begin{array}{c}\text { BREAST CANCER } \\
\text { 4T1 cells angiogenesis } \\
\text { suppression }\end{array}$ & Animal model (mice) & Jiang M. et al., 2020 [71] \\
\hline PTX-SB-Dex-DOCA & $\begin{array}{c}\text { LUNG CANCER } \\
\text { inhibition of tumour } \\
\text { growth A549 cells }\end{array}$ & Animal model (mice) & Huo M. et al. 2020 [70] \\
\hline S/C-pW nanoparrticles & $\begin{array}{c}\text { BREAST CANCER } \\
\text { anti-metastasis activity }\end{array}$ & Animal model (mice) & Liu Y. et al., 2020 [72] \\
\hline
\end{tabular}

\section{Apigenin}

Apigenin is found in several types of vegetables and fruits, especially berries. This flavonoid is involved in regulating signalling pathways in hepatocellular carcinoma and skin cancer. The beneficial effect of free apigenin in cancer treatment is relatively low because of its low lipid and water solubility [73]. Nowadays, to improve the bioavailability of flavonoids, PLGA nanoparticles are mainly used. A study by Das et al. showed an anti-proliferative effect of apigenin loaded in PLGA nanoparticles on A475 skin cancer cells. It is worth emphasizing that these nanoparticles were effective in maintaining photodegradation through ultraviolet light [74]. Other study on apigenin encapsulated in PLGA nanoparticles showed that intravenous administration of this molecules successfully reached HepG2 and Huh-7 cells in vitro as well as the liver of carcinogenic animals and delayed development of hepatocellular carcinoma in rats [75]. Novel nanomaterials have recently been investigated, which contribute to enhanced solubility and bioavailability of apigenin via preparation of solid dispersions of mesoporous silica nanoparticles [76]. The anticancer effects of apigenin nanoparticles are reported in Table 5.

Table 5. Anticancer effect of apigenin nanoparticles in in vivo studies.

\begin{tabular}{cccc}
\hline Nanomaterial Type & Cancer Type/Effect & Study Type & Reference \\
\hline \multirow{3}{*}{ PLGA } & $\begin{array}{c}\text { SKIN CANCER } \\
\text { A375 cells reduction in markers of } \\
\text { proliferative activity increased } \\
\text { ROS production and } \\
\text { mitochondrial-induced apoptosis }\end{array}$ & Animal model (mice) & $\begin{array}{c}\text { Das S. et al., 2013 } \\
\text { [74] }\end{array}$ \\
\cline { 2 - 4 } & $\begin{array}{c}\text { HEPATOCELLULAR } \\
\text { CARCINOMA inhibition effect on } \\
\text { cancer cells HepG2 and } \\
\text { Huh-7 cells }\end{array}$ & Animal model (rats) & $\begin{array}{c}\text { Bhattacharya S. et } \\
\text { al., 2018 [75] }\end{array}$ \\
\hline $\begin{array}{c}\text { MSN } \\
\text { mesoporous silica } \\
\text { nanoparticles }\end{array}$ & $\begin{array}{c}\text { improved solubility, dissolution, } \\
\text { and bioavailability after oral } \\
\text { application }\end{array}$ & Animal model (rats) & $\begin{array}{c}\text { Huang Y., et al., } \\
\text { 2019 [76] }\end{array}$ \\
\hline
\end{tabular}




\section{Naringenin}

Naringenin is widely distributed in fruits, especially citrus fruits, bergamot, and tomatoes [77]. Its anticancer properties are associated with anti-inflammatory and antioxidant activities. The clinical effect of cancer treatment with naringenin is limited by its low solubility and minimal bioavailability, related to its hydrophobic ring structure [78].

Current research has shown that naringenin nanoparticles can inhibit carcinogenesis in oral squamous cell carcinoma [79], lung cancer (A549) [80], and colorectal cancer (colon-26) [81]. Due to their anti-proliferative and antioxidant potential, nanoparticles can be potentially useful in oral cancer chemoprevention $[79,82]$. In the Sulfikkarali et al. study, PVA-EE (polyvinyl alcohol and Eudragit 500) loaded with naringenin had a positive effect on DMBA-induced oral squamous cell carcinoma in hamsters. The oral administration of PVA-EE-naringenin completely prevented the tumour formation as compared to the free naringenin [79]. Chitosan nanoparticles encapsulating naringenin were used in an in vitro lung cancer model (A549), reporting cytotoxic effects on the cancer cells while having a nontoxic effect on normal 3T3 fibroblast cells [80]. The Chaurasia et al. study has described tumour suppression in BALB/c mice bearing colon-26 cells. Both naringenin-encapsulated soluthin-maltodextrin nanoparticles and EE-naringenin improve bioavailability and have a cytotoxic effect against colorectal cancer cells $[32,33]$. The Fuster et al. study reported that naringenin loaded in silk fibroin nanoparticles had anticancer potential for treatment of cervical cancer HeLa cells [78] (Table 6).

Table 6. Anticancer effect of naringenin nanoparticles in in vivo studies.

\begin{tabular}{|c|c|c|c|}
\hline Nanomaterial Type & Cancer Type/Effect & Study Type & Reference \\
\hline $\begin{array}{c}\text { PVA-eudragit } \\
\text { poly vinyl } \\
\text { alcohol-Eudragit } 500\end{array}$ & $\begin{array}{l}\text { ORAL SQUAMOUS CELL } \\
\text { CARCINOMA anti-tumour effect }\end{array}$ & $\begin{array}{l}\text { Animal model } \\
\text { (hamster) }\end{array}$ & $\begin{array}{l}\text { Krishnakumar N. } \\
\text { et al., } 2013 \text { [79] }\end{array}$ \\
\hline Eudragit & $\begin{array}{c}\text { ORAL SQUAMOUS CELL } \\
\text { CARCINOMA } \\
\text { prevention of the tumour } \\
\text { formation, reduction of the degree } \\
\text { of histological lesions, anti-lipid } \\
\text { peroxidative effect, } \\
\text { anti-proliferative effect, } \\
\text { antioxidant potential }\end{array}$ & $\begin{array}{l}\text { Animal model } \\
\text { (hamster) }\end{array}$ & $\begin{array}{l}\text { Sulfikkarali N. et } \\
\text { al., } 2013 \text { [82] }\end{array}$ \\
\hline Chitosan & $\begin{array}{c}\text { LUNG CANCER } \\
\text { antioxidant and anticancer } \\
\text { activities (A549 cells) }\end{array}$ & In vitro model & $\begin{array}{l}\text { Kumar S. P. et al., } \\
2015 \text { [80] }\end{array}$ \\
\hline Soluthin-maltodextrin & $\begin{array}{l}\text { COLORECTAL CANCER } \\
\text { enhanced oral bioavailability, } \\
\text { tumour suppression in BALB/c } \\
\text { mice-bearing colon- } 26 \text { cells }\end{array}$ & $\begin{array}{l}\text { Animal model } \\
\text { (rats) }\end{array}$ & $\begin{array}{c}\text { Chaurasia S. et al., } \\
2017 \text { [81] }\end{array}$ \\
\hline $\begin{array}{l}\text { NRG-EE100-NPs } \\
\text { (Eudragit 100) }\end{array}$ & $\begin{array}{l}\text { COLORECTAL CANCER } \\
\text { enhanced oral bioavailability, } \\
\text { tumour suppression in BALB/c } \\
\text { mice-bearing colon- } 26 \text { cells }\end{array}$ & $\begin{array}{l}\text { Animal model } \\
\text { (rats) }\end{array}$ & $\begin{array}{c}\text { Chaurasia S. et al., } \\
2018 \text { [83] }\end{array}$ \\
\hline Silk fibroin nanoparticles & $\begin{array}{c}\text { CERVICAL CANCER } \\
\text { anticancer potential HeLa cells }\end{array}$ & In vitro model & $\begin{array}{l}\text { Fuster M. G. et al., } \\
2020[78]\end{array}$ \\
\hline
\end{tabular}

\section{Luteolin}

Luteolin is found in various types of plants such as fruits, vegetables, and medicinal herbs [84]. It induces apoptosis and inhibits cancer cell migration, invasion, and angiogenesis [85]. Due to its hydrophobic structure, it has poor water solubility, poor systemic delivery, and low efficacy. To improve the effect of luteolin, nanoparticles, i.e., PLA-PEG and folic acid-PEG-PCL have been used [86].

One in vitro study concluded that water-soluble polymer-encapsulated nano-luteolin from hydrophobic luteolin (PLA-PEG) inhibited the growth of lung cancer cells (H292 cell line) and 
squamous cell carcinoma of head and neck (SCCHN) cells (Tu212 cell line) [86], which are among the most frequent cancers worldwide [87-89]. Moreover, in vivo study using a tumour xenograft mouse model demonstrated that nano-luteolin has a significant inhibitory effect on the tumour growth of SCCHN in comparison to free luteolin [86]. The study by Wu et al. study showed that luteolin encapsulated in folic acid modifiedpoly(ethylene glycol)-poly(ecaprolactone) (Fa-PEG-PCL) nano-micelles induced glioblastoma multiforme growth of GL261 cells [90]. Additionally, in the safety assessment of nanoparticles used in the tested mice, there were no obvious side effects [90]. Due to the fact that luteolin is hydrophobic [91] and has low biocompatibility [90], it still requires further studies to improve its bioavailability (Table 7).

Table 7. Anticancer effect of luteolin nanoparticles in in vivo studies.

\begin{tabular}{cccc}
\hline Nanomaterial Type & Cancer Type/Effect & Study Type & Reference \\
\hline PLA-PEG & LUNG CANCER and & Animal model (mice) & Majumdar \\
& $\begin{array}{c}\text { HEAD AND NECK CANCER } \\
\text { inhibition of tumour growth } \\
\text { H292, Tu212 cells }\end{array}$ & & \\
& D. et al., 2014 [86] \\
Fa-PEG-PCL & GLIOBLASTOMA & Animal model (mice) & Wu C. et al., 2019 \\
& $\begin{array}{c}\text { [90] } \\
\text { inhibition and apoptosis of } \\
\text { GL261 cells }\end{array}$ & \\
\hline
\end{tabular}

\section{Kaempferol}

Kaempferol is widely distributed in vegetables (broccoli, spinach), fruits (strawberries, apples), and herbal medicines [92]. The limitation of free kaempferol is inefficient systemic delivery and limited bioavailability [93]. Promising nanoparticles to improve the anticancer efficacy of this flavonoid are chitosan, gold, and PLGA. The potential anticancer effect of this flavonoid is associated with inhibition of phosphatidylinositol-3-kinase (Pl-3) and ribosomal s6 kinase (rsk) and cell cycle arrest in various cancer types [94]. In vitro studies have demonstrated that kaempferol nanoparticles can inhibit carcinogenesis in ovarian cancer cells (A2780/CP70 and OVCAR-3) [93], rat glioma cells (C6) [95] and lung cancer cells (A549) [96]. In the study by Luo et al. both PEO-PPO-PEO as well as PLGA nanoparticles formulations incorporating kaempferol significantly reduced viability of ovarian cancer cells (A2780/CP70 and OVCAR-3), compared with kaempferol alone [93]. The PEO-PPO-PEO nanoparticles were more effective than PLGA nanoparticles, however, PEO-PPO-PEO nanoparticles reduced the viability of ovarian cancer cells (OVCAR-3) and normal ovarian cells (IOSE397), while PLGA nanoparticles had selective toxicity and reduced only the viability of ovarian cancer cells (OVCAR-3) [93]. In another study, kaempferol-loaded mucoadhesive chitosan nanoemulsion (MNE) was used to induce glioma cell in rats [95]. The kaempferol-loaded MNE reduced C6 glioma cell viability a greater degree than free kaempferol. Therefore, kaempferol-loaded mucoadhesive chitosan nanoemulsion could be a promising alternative for brain cancer treatment [95]. The Govindaraju et al. study reported that kaempferol with gold nanoparticles had higher toxicity to A549 lung cancer cells than to normal human cells [96] (Table 8). 
Table 8. Anticancer effect of kaempferol nanoparticles in in vitro studies.

\begin{tabular}{cccc}
\hline Nanomaterial Type & Cancer Type/Effect & Study Type & Reference \\
\hline PEO-PPO-PEO, PLGA & $\begin{array}{c}\text { OVARIAN CANCER } \\
\text { strong and selective inhibition of } \\
\text { cancer cell viability A2780/CP70 and } \\
\text { OVCAR-3 ovarian cancer cell lines }\end{array}$ & In vitro model & $\begin{array}{c}\text { Luo H. et al., 2012 } \\
\text { [93] }\end{array}$ \\
\hline Chitosan & $\begin{array}{c}\text { BRAIN CANCER } \\
\text { induction of apoptosis C6 rat glioma } \\
\text { cell line }\end{array}$ & In vitro model & $\begin{array}{c}\text { Colombo M. } \\
\text { et al., 2018 [95] }\end{array}$ \\
\hline Gold & $\begin{array}{c}\text { LUNG CANCER } \\
\text { cytotoxic effect on A549 lung cancer } \\
\text { cells }\end{array}$ & In vitro model & $\begin{array}{c}\text { Govindaraju S. } \\
\text { et al., 2019 [96] }\end{array}$ \\
\hline
\end{tabular}

\section{Other Flavonoids (Fisetin and Myricetin)}

Fisetin is found in various fruits and vegetables (e.g., apple, strawberry, grape, persimmon, onion) [97]. In the Ghosh et al. study, fisetin-loaded human serum albumin nanoparticles revealed anticancer activity against MCF-7 breast cancer cells in vitro [98]. The Feng et al. study confirmed the effect of fistein nanoparticles on $4 \mathrm{~T} 1$ breast cancer cells in vivo. Additionally, in vitro fistein-loaded PLA nanoparticles had an anti-tumour effect against colon cancer HCT116 cells [99].

Myricetin is very common in various plants, such as vegetables, fruits, and in teas and wines [100]. In vitro myricetin encapsulated in solid Gelucire-based lipid nanoparticles in the presence of phosphate buffer provided sustained release with no signs of degradation [101]. In the Khorsandi et al. study, solid lipid nanoparticles of myricetin induced growth of lung cancer A549 cells and increased necrosis with no influence on proliferation and apoptosis [102].

The anticancer effects of fisetin and myricetin nanoparticles are presented in Table 9.

Table 9. Anticancer effect of fisetin and myricetin nanoparticles in vitro and in vivo studies.

\begin{tabular}{|c|c|c|c|c|}
\hline Flavonoid & $\begin{array}{c}\text { Nanomaterial } \\
\text { Type }\end{array}$ & Cancer Type/Effect & Study Type & Reference \\
\hline \multirow[b]{2}{*}{ Fisetin } & $\begin{array}{l}\text { HAS (human } \\
\text { serum albumin) }\end{array}$ & $\begin{array}{c}\text { BREAST CANCER } \\
\text { cytotoxic effect on MCF-7 } \\
\text { cells }\end{array}$ & In vitro model & $\begin{array}{c}\text { Ghosh P. et al., } \\
2016 \text { [98] }\end{array}$ \\
\hline & PLA & $\begin{array}{l}\text { BREAST CANCER and } \\
\text { COLON CANCER } \\
\text { cytotoxicity assay against } \\
\text { HCT116 colon cancer cells } \\
\text { in vitro and anti-tumour test } \\
\text { in a xenograft } 4 \text { T1 breast } \\
\text { cancer model in vivo } \\
\text { demonstrated the } \\
\text { anti-tumour effect }\end{array}$ & $\begin{array}{l}\text { In vitro and } \\
\text { animal model } \\
\text { (rats) }\end{array}$ & $\begin{array}{l}\text { Feng C. et al., } \\
2019 \text { [99] }\end{array}$ \\
\hline Myricetin & $\begin{array}{l}\text { SLNs solid lipid } \\
\text { nanoparticles }\end{array}$ & $\begin{array}{l}\text { LUNG CANCER induction } \\
\text { of cell growth necrosis } \\
\text { (A549 cells) }\end{array}$ & In vitro model & $\begin{array}{l}\text { Khorsandi L. } \\
\text { et al., } 2020 \text { [102] }\end{array}$ \\
\hline
\end{tabular}

Flavonoids, a ubiquitous group of naturally occurring polyphenolic compounds, have recently gained importance as anticancer agents. Unfortunately, due to low solubility, absorption, and rapid metabolism of dietary flavonoids, their anticancer potential is not sufficient. The use of nanotechnology has improved the bioavailability of flavonoids and has increased their anti-tumour activity.

Both in vitro and in vivo studies have shown that flavonoid nanoparticles are promising in cancer treatment in the near future. Most of the studies determining the anticancer properties of flavonoid 
nanoparticles are preclinical. The potential anticancer activity focuses mainly on MCF-7 breast cancer cells, A549 lung cancer cells, HepG2 liver cancer cells, and melanoma cells.

The anticancer activity of flavonoid nanoparticles is associated with apoptosis and antiproliferation, inhibition of the cell cycle of cancer cells, regulation of the host's immune system or an anti-inflammatory effect. A particular issue worth investigation is the influence of nanoparticles on the tumour microenvironment, which may be quite important in metastasis.

It is worth noting that flavonoid nanoparticles can also support the anti-tumour effect of drugs used in cancer therapy by enhancing the anti-tumour effect or by reducing the systemic toxicity of drugs.

Author Contributions: Manuscript preparation: M.D., M.N. and E.F. Conceptualization: M.N. and E.F.; formal analysis: M.D.; writing and original draft preparation: M.D. and M.N.; writing review and editing: M.D., M.N. and E.F.; supervision, M.N. and E.F. All authors have read and agreed to the published version of the manuscript.

Funding: This review was written with no external funding.

Conflicts of Interest: The authors declare no conflict of interest.

\section{References}

1. Khan, H.; Ullah, H.; Martorell, M.; Valdes, S.E.; Belwal, T.; Tejada, S.; Sureda, A.; Kamal, M.A. Flavonoids nanoparticles in cancer: Treatment, prevention and clinical prospects. Semin. Cancer Biol. 2019, 57, 72-78. [CrossRef] [PubMed]

2. Kumar, S.; Pandey, A.K. Chemistry and Biological Activities of Flavonoids: An Overview. Sci. World J. 2013, 2013, 1-16. [CrossRef] [PubMed]

3. Procházková, D.; Boušová, I.; Wilhelmová, N. Antioxidant and prooxidant properties of flavonoids. Fitoterapia 2011, 82, 513-523. [CrossRef]

4. Serafini, M.; Peluso, I.; Raguzzini, A. Flavonoids as anti-inflammatory agents. Proc. Nutr. Soc. 2010, 69, 273-278. [CrossRef] [PubMed]

5. Gontijo, V.S.; dos Santos, M.H.; Viegas, C., Jr. Biological and Chemical Aspects of Natural Biflavonoids from Plants: A Brief Review. Mini Rev. Med. Chem. 2017, 17, 834-862. [CrossRef]

6. Thilakarathna, S.; Rupasinghe, H. Flavonoid Bioavailability and Attempts for Bioavailability Enhancement. Nutrients 2013, 5, 3367-3387. [CrossRef]

7. Cassidy, A.; Minihane, A.M. The role of metabolism (and the microbiome) in defining the clinical efficacy of dietary flavonoids. Am. J. Clin. Nutr. 2017, 105, 10-22. [CrossRef] [PubMed]

8. de Pace, R.C.C.; Liu, X.; Sun, M.; Nie, S.; Zhang, J.; Cai, Q.; Gao, W.; Pan, X.; Fan, Z.; Wang, S. Anticancer activities of (-)-epigallocatechin-3-gallate encapsulated nanoliposomes in MCF7 breast cancer cells. J. Liposome Res. 2013, 23, 187-196. [CrossRef]

9. Tan, B.J.; Liu, Y.; Chang, K.J.; Lim, B.K.W.; Chiu, G.N.C. Perorally active nanomicellar formulation of quercetin in the treatment of lung cancer. Int. J. Nanomed. 2012, 7, 651-661. [CrossRef]

10. Jain, A.K.; Thanki, K.; Jain, S. Co-encapsulation of Tamoxifen and Quercetin in Polymeric Nanoparticles: Implications on Oral Bioavailability, Anti-tumour Efficacy, and Drug-Induced Toxicity. Mol. Pharm. 2013, 10, 3459-3474. [CrossRef]

11. Xu, G.; Shi, H.; Ren, L.; Gou, H.; Gong, D.; Gao, X.; Huang, N. Enhancing the anti-colon cancer activity of quercetin by self-assembled micelles. Int. J. Nanomed. 2015, 10, 2051-2063. [CrossRef]

12. Wu, B.; Liang, Y.; Tan, Y.; Xie, C.; Shen, J.; Zhang, M.; Liu, X.; Yang, L.; Zhang, F.; Liu, L.; et al. Genistein-loaded nanoparticles of star-shaped diblock copolymer mannitol-core PLGA-TPGS for the treatment of liver cancer. Mater. Sci. Eng. C 2016, 59, 792-800. [CrossRef]

13. Joshi, M.D.; Patravale, V.; Prabhu, R. Polymeric nanoparticles for targeted treatment in oncology: Current insights. Int. J. Nanomed. 2015, 10, 1001-1018. [CrossRef] [PubMed]

14. Kothamasu, P.; Kanumur, H.; Ravur, N.; Maddu, C.; Parasuramrajam, R.; Thangavel, S. Nanocapsules: The Weapons for Novel Drug Delivery Systems. Bioimpacts 2012, 2, 71-81. [CrossRef] [PubMed]

15. Jain, S.; Hirst, D.G.; O'Sullivan, J.M. Gold nanoparticles as novel agents for cancer therapy. Br. J. Radiol. 2012, 85, 101-113. [CrossRef] [PubMed] 
16. Mu, H.; Holm, R. Solid lipid nanocarriers in drug delivery: Characterization and design. Expert Opin. Drug Deliv. 2018, 15, 771-785. [CrossRef]

17. Mukherjee, S.; Ghosh, S.; Das, D.K.; Chakraborty, P.; Choudhury, S.; Gupta, P.; Adhikary, A.; Dey, S.; Chattopadhyay, S. Gold-conjugated green tea nanoparticles for enhanced anti-tumour activities and hepatoprotection - synthesis, characterization and in vitro evaluation. J. Nutr. Biochem. 2015, 26, 1283-1297. [CrossRef]

18. Zan, L.; Chen, Q.; Zhang, L.; Li, X. Epigallocatechin gallate (EGCG) suppresses growth and tumourigenicity in breast cancer cells by downregulation of miR-25. Bioengineered 2019, 10, 374-382. [CrossRef]

19. Cai, Z.Y.; Li, X.M.; Liang, J.P.; Xiang, L.P.; Wang, K.R.; Shi, Y.L.; Yang, R.; Shi, M.; Ye, J.H.; Lu, J.L.; et al. Bioavailability of Tea Catechins and Its Improvement. Molecules 2018, 23, 2346. [CrossRef]

20. Lambert, J.D.; Kennett, M.J.; Sang, S.; Reuhl, K.R.; Ju, J.; Yang, C.S. Hepatotoxicity of high oral dose (-)-epigallocatechin-3-gallate in mice. Food Chem. Toxicol. 2010, 48, 409-416. [CrossRef]

21. Siddiqui, I.A.; Adhami, V.M.; Bharali, D.J.; Hafeez, B.B.; Asim, M.; Khwaja, S.I.; Ahmad, N.; Cui, H.; Mousa, S.A.; Mukhtar, H. Introducing Nanochemoprevention as a Novel Approach for Cancer Control: Proof of Principle with Green Tea Polyphenol Epigallocatechin-3-Gallate. Cancer Res. 2009, 69, 1712-1716. [CrossRef] [PubMed]

22. Peng, J.; Liang, X. Progress in research on gold nanoparticles in cancer management. Medicine (Baltimore) 2019, 98, e15311. [CrossRef] [PubMed]

23. Hsieh, D.S.; Wang, H.; Tan, S.W.; Huang, Y.H.; Tsai, C.Y.; Yeh, M.K.; Wu, C.J. The treatment of bladder cancer in a mouse model by epigallocatechin-3-gallate-gold nanoparticles. Biomaterials 2011, 32, 7633-7640. [CrossRef] [PubMed]

24. Hsieh, D.S.; Cheng, C.C.; Wu, C.J.; Yeh, M.K. The preparation and characterization of gold-conjugated polyphenol nanoparticles as a novel delivery system. Int. J. Nanomed. 2012, 7, 1623-1633. [CrossRef]

25. Shukla, R.; Chanda, N.; Zambre, A.; Upendran, A.; Katti, K.; Kulkarni, R.R.; Nune, S.K.; Casteel, S.W.; Smith, C.J.; Vimal, J.; et al. Laminin receptor specific therapeutic gold nanoparticles (198AuNP-EGCg) show efficacy in treating prostate cancer. Proc. Natl. Acad. Sci. USA 2012, 109, 12426-12431. [CrossRef]

26. Chen, C.C.; Hsieh, D.S.; Huang, K.J.; Chan, Y.L.; Hong, P.D.; Yeh, M.K.; Wu, C.J. Improving anticancer efficacy of (-)-epigallocatechin-3-gallate gold nanoparticles in murine B16F10 melanoma cells. Drug Des. Devel. Ther. 2014, 8, 459-474. [CrossRef]

27. Rocha, S.; Generalov, R.; Pereira, M.D.C.; Peres, I.; Juzenas, P.; Coelho, M.A. Epigallocatechin gallate-loaded polysaccharide nanoparticles for prostate cancer chemoprevention. Nanomedicine 2011, 6, 79-87. [CrossRef]

28. Peres, I.; Rocha, S.; Gomes, J.; Morais, S.; Pereira, M.C.; Coelho, M. Preservation of catechin antioxidant properties loaded in carbohydrate nanoparticles. Carbohydr. Polym. 2011, 86, 147-153. [CrossRef]

29. Siddiqui, I.A.; Bharali, D.J.; Nihal, M.; Adhami, V.M.; Khan, N.; Chamcheu, J.C.; Khan, M.I.; Shabana, S.; Mousa, S.A.; Mukhtar, H. Excellent anti-proliferative and pro-apoptotic effects of (-)-epigallocatechin-3-gallate encapsulated in chitosan nanoparticles on human melanoma cell growth both in vitro and in vivo. Nanomed. 2014, 10, 1619-1626. [CrossRef]

30. Khan, N.; Bharali, D.J.; Adhami, V.M.; Siddiqui, I.A.; Cui, H.; Shabana, S.M.; Mousa, S.A.; Mukhtar, H. Oral administration of naturally occurring chitosan-based nanoformulated green tea polyphenol EGCG effectively inhibits prostate cancer cell growth in a xenograft model. Carcinogenesis 2014, 35, 415-423. [CrossRef]

31. Zeng, L.; Yan, J.; Luo, L.; Ma, M.; Zhu, H. Preparation and characterization of (-)-Epigallocatechin-3-gallate (EGCG)-loaded nanoparticles and their inhibitory effects on Human breast cancer MCF-7 cells. Sci. Rep. 2017, 7, 45521. [CrossRef] [PubMed]

32. Lin, Y.H.; Chen, Z.R.; Lai, C.H.; Hsieh, C.H.; Feng, C.L. Active Targeted Nanoparticles for Oral Administration of Gastric Cancer Therapy. Biomacromolecules 2015, 16, 3021-3032. [CrossRef] [PubMed]

33. Liao, B.; Ying, H.; Yu, C.; Fan, Z.; Zhang, W.; Shi, J.; Ying, H.; Ravichandran, N.; Xu, Y.; Yin, J.; et al. (-)-Epigallocatechin gallate (EGCG)-nanoethosomes as a transdermal delivery system for docetaxel to treat implanted human melanoma cell tumours in mice. Int. J. Pharm. 2016, 512, 22-31. [CrossRef] [PubMed]

34. Tang, P.; Sun, Q.; Yang, H.; Tang, B.; Pu, H.; Li, H. Honokiol nanoparticles based on epigallocatechin gallate functionalized chitin to enhance therapeutic effects against liver cancer. Int. J. Pharm. 2018, 545, 74-83. [CrossRef] 
35. Srivastava, S.; Somasagara, R.R.; Hegde, M.; Nishana, M.; Tadi, S.K.; Srivastava, M.; Choudhary, B.; Raghavan, S.C. Quercetin, a Natural Flavonoid Interacts with DNA, Arrests Cell Cycle and Causes Tumour Regression by Activating Mitochondrial Pathway of Apoptosis. Sci. Rep. 2016, 6, 24049. [CrossRef] [PubMed]

36. Xing, L.; Lyu, J.Y.; Yang, Y.; Cui, P.F.; Gu, L.Q.; Qiao, J.B.; He, Y.J.; Zhang, T.Q.; Sun, M.; Lu, J.J.; et al. $\mathrm{pH}$-Responsive de-PEGylated nanoparticles based on triphenylphosphine-quercetin self-assemblies for mitochondria-targeted cancer therapy. Chem. Commun. (Camb.) 2017, 53, 8790-8793. [CrossRef] [PubMed]

37. Niazvand, F.; Orazizadeh, M.; Khorsandi, L.; Abbaspour, M.; Mansouri, E.; Khodadadi, A. Effects of Quercetin-Loaded Nanoparticles on MCF-7 Human Breast Cancer Cells. Medicina (Kaunas) 2019, 55, 114. [CrossRef] [PubMed]

38. Tang, S.H.; Li, R.; Tan, J.; Wang, Y.; Jiang, Z.T. One pot synthesis of water-soluble quercetin derived multifunctional nanoparticles with photothermal and antioxidation capabilities. Colloids Surf. B Biointerfaces 2019, 183, 110429. [CrossRef]

39. Lou, M.; Zhang, L.; Ji, P.; Feng, F.; Liu, J.; Yang, C.; Li, B.; Wang, L. Quercetin nanoparticles induced autophagy and apoptosis through AKT/ERK/Caspase-3 signaling pathway in human neuroglioma cells: In vitro and in vivo. Biomed. Pharm. 2016, 84, 1-9. [CrossRef]

40. Wang, G.; Wang, J.J.; Chen, X.L.; Du, L.; Li, F. Quercetin-loaded freeze-dried nanomicelles: Improving absorption and anti-glioma efficiency in vitro and in vivo. J. Control. Release 2016, 235, 276-290. [CrossRef]

41. Li, J.; Shi, M.; Ma, B.; Niu, R.; Zhang, H.; Kun, L. Anti-tumour activity and safety evaluation of nanaparticle-based delivery of quercetin through intravenous administration in mice. Mater. Sci. Eng. C 2017, 77, 803-810. [CrossRef] [PubMed]

42. Ghosh, A.; Ghosh, D.; Sarkar, S.; Mandal, A.K.; Thakur Choudhury, S.; Das, N. Anticarcinogenic activity of nanoencapsulated quercetin in combating diethylnitrosamine-induced hepatocarcinoma in rats. Eur. J. Cancer Prev. 2012, 21, 32-41. [CrossRef] [PubMed]

43. Mandal, A.K.; Ghosh, D.; Sarkar, S.; Ghosh, A.; Swarnakar, S.; Das, N. Nanocapsulated quercetin downregulates rat hepatic MMP-13 and controls diethylnitrosamine-induced carcinoma. Nanomedicine 2014, 9, 2323-2337. [CrossRef] [PubMed]

44. Ren, K.W.; Li, Y.H.; Wu, G.; Ren, J.Z.; Lu, H.B.; Li, Z.M.; Han, X.W. Quercetin nanoparticles display anti-tumour activity via proliferation inhibition and apoptosis induction in liver cancer cells. Int. J. Oncol. 2017, 50, 1299-1311. [CrossRef]

45. Pandey, P.; Rahman, M.; Bhatt, P.C.; Beg, S.; Paul, B.; Hafeez, A.; Al-Abbasi, F.A.; Nadeem, M.S.; Baothman, O.; Anwar, F; et al. Implication of nano-antioxidant therapy for treatment of hepatocellular carcinoma using PLGA nanoparticles of rutin. Nanomedicine 2018, 13, 849-870. [CrossRef]

46. Guan, X.; Gao, M.; Xu, H.; Zhang, C.; Liu, H.; Lv, L.; Deng, S.; Gao, D.; Tian, Y. Quercetin-loaded poly (lactic- co -glycolic acid)- d - $\alpha$-tocopheryl polyethylene glycol 1000 succinate nanoparticles for the targeted treatment of liver cancer. Drug Deliv. 2016, 23, 3307-3318. [CrossRef]

47. Wang, S.; Su, R.; Nie, S.; Sun, M.; Zhang, J.; Wu, D.; Moustaid-Moussa, N. Application of nanotechnology in improving bioavailability and bioactivity of diet-derived phytochemicals. J. Nutr. Biochem. 2014, 25, 363-376. [CrossRef]

48. Dora, C.L.; Costa Silva, L.F.; Mazzarino, L.; Siqueira, J.M.; Fernandes, D.; Pacheco, L.K.; Maioral, M.F.; Santos-Silva, M.C.; Muccillo Baisch, A.L.; Assreuy, J.; et al. Oral Delivery of a High Quercetin Payload Nanosized Emulsion: In Vitro and In Vivo Activity Against B16-F10 Melanoma. J. Nanosci. Nanotechnol. 2016, 16, 1275-1281. [CrossRef]

49. Long, Q.; Xie, Y.; Huang, Y.; Wu, Q.; Zhang, H.; Xiong, S.; Liu, Y.; Chen, L.; Wei, Y.; Zhao, X.; et al. Induction of Apoptosis and Inhibition of Angiogenesis by PEGylated Liposomal Quercetin in Both Cisplatin-Sensitive and Cisplatin-Resistant Ovarian Cancers. J. Biomed. Nanotechnol. 2013, 9, 965-975. [CrossRef]

50. Zhao, J.; Liu, J.; Wei, T.; Ma, X.; Cheng, Q.; Huo, S.; Zhang, C.; Zhang, Y.; Duan, X.-L.; Liang, X.-J.; et al. Quercetin-loaded nanomicelles to circumvent human castration-resistant prostate cancer in vitro and in vivo. Nanoscale 2016, 8, 5126-5138. [CrossRef]

51. Gao, X.; Wang, B.; Wei, X.; Men, K.; Zheng, F.; Zhou, Y.; Zheng, Y.; Gou, M.; Huang, M.; Guo, G.; et al. Anticancer effect and mechanism of polymer micelle-encapsulated quercetin on ovarian cancer. Nanoscale 2012, 4, 7021-7030. [CrossRef] [PubMed] 
52. Sharma, G.; Park, J.; Sharma, A.R.; Jung, J.-S.; Kim, H.; Chakraborty, C.; Song, D.K.; Lee, S.-S.; Nam, J.-S. Methoxy Poly(ethylene glycol)-Poly(lactide) Nanoparticles Encapsulating Quercetin Act as an Effective Anticancer Agent by Inducing Apoptosis in Breast Cancer. Pharm. Res. 2015, 32, 723-735. [CrossRef] [PubMed]

53. Jain, A.S.; Shah, S.M.; Nagarsenker, M.S.; Nikam, Y.; Gude, R.P.; Steiniger, F.; Thamm, J.; Fahr, A. Lipid Colloidal Carriers for Improvement of Anticancer Activity of Orally Delivered Quercetin: Formulation, Characterization and Establishing In Vitro-In Vivo Advantage. J. Biomed. Nanotechnol. 2013, 9, 1230-1240. [CrossRef] [PubMed]

54. da Luz, C.M.; Boyles, M.S.P.; Falagan-Lotsch, P.; Pereira, M.R.; Tutumi, H.R.; de Oliveira Santos, E.; Martins, N.B.; Himly, M.; Sommer, A.; Foissner, I.; et al. Poly-lactic acid nanoparticles (PLA-NP) promote physiological modifications in lung epithelial cells and are internalized by clathrin-coated pits and lipid rafts. J. Nanobiotechnol. 2017, 15, 11. [CrossRef]

55. Luo, C.L.; Liu, Y.Q.; Wang, P.; Song, C.H.; Wang, K.J.; Dai, L.P.; Zhang, J.Y.; Ye, H. The effect of quercetin nanoparticle on cervical cancer progression by inducing apoptosis, autophagy and anti-proliferation via JAK2 suppression. Biomed. Pharmacother. 2016, 82, 595-605. [CrossRef]

56. Kaufman, P.B.; Duke, J.A.; Brielmann, H.; Boik, J.; Hoyt, J.E. A Comparative Survey of Leguminous Plants as Sources of the Isoflavones, Genistein and Daidzein: Implications for Human Nutrition and Health. J. Altern. Complement. Med. 1997, 3, 7-12. [CrossRef]

57. Rassu, G.; Porcu, E.P.; Fancello, S.; Obinu, A.; Senes, N.; Galleri, G.; Migheli, R.; Gavini, E.; Giunchedi, P. Intranasal Delivery of Genistein-Loaded Nanoparticles as a Potential Preventive System against Neurodegenerative Disorders. Pharmaceutics 2018, 11, 8. [CrossRef]

58. Zhang, H.; Liu, G.; Zeng, X.; Wu, Y.; Yang, C.; Mei, L.; Wang, Z.; Huang, L. Fabrication of genistein-loaded biodegradable TPGS-b-PCL nanoparticles for improved therapeutic effects in cervical cancer cells. Int. J. Nanomed. 2015, 10, 2461-2473. [CrossRef]

59. Pool, H.; Campos-Vega, R.; Herrera-Hernández, M.G.; García-Solis, P.; García-Gasca, T.; Sánchez, I.C.; Luna-Bárcenas, G.; Vergara-Castañeda, H. Development of genistein-PEGylated silica hybrid nanomaterials with enhanced antioxidant and antiproliferative properties on HT29 human colon cancer cells. Am. J. Transl. Res. 2018, 10, 2306-2323.

60. Spagnuolo, C.; Russo, G.L.; Orhan, I.E.; Habtemariam, S.; Daglia, M.; Sureda, A.; Nabavi, S.F.; Devi, K.P.; Loizzo, M.R.; Tundis, R.; et al. Genistein and Cancer: Current Status, Challenges, and Future Directions. Adv. Nutr. 2015, 6, 408-419. [CrossRef]

61. Sacko, K.; Thangavel, K.; Shoyele, S.A. Codelivery of Genistein and miRNA-29b to A549 Cells Using Aptamer-Hybrid Nanoparticle Bioconjugates. Nanomaterials 2019, 9, 1052. [CrossRef] [PubMed]

62. Ghasemi, G.R.; Mohammadi, M.R.; Malekzadeh, K. Synthesizing efficacious genistein in conjugation with superparamagnetic $\mathrm{Fe} 3 \mathrm{O} 4$ decorated with bio-compatible carboxymethylated chitosan against acute leukemia lymphoma. Biomater. Res. 2020, 24, 9. [CrossRef] [PubMed]

63. Mateen, S.; Tyagi, A.; Agarwal, C.; Singh, R.P.; Agarwal, R. Silibinin inhibits human nonsmall cell lung cancer cell growth through cell-cycle arrest by modulating expression and function of key cell-cycle regulators. Mol. Carcinog. 2009, 49, 247-258. [CrossRef] [PubMed]

64. Hogan, F.S.; Krishnegowda, N.K.; Mikhailova, M.; Kahlenberg, M.S. Flavonoid, Silibinin, Inhibits Proliferation and Promotes Cell-Cycle Arrest of Human Colon Cancer. J. Surg. Res. 2007, 143, 58-65. [CrossRef] [PubMed]

65. Yazdi Rouholamini, S.E.; Moghassemi, S.; Maharat, Z.; Hakamivala, A.; Kashanian, S.; Omidfar, K. Effect of silibinin-loaded nano-niosomal coated with trimethyl chitosan on miRNAs expression in 2D and 3D models of T47D breast cancer cell line. Artif. Cells Nanomed. Biotechnol. 2018, 46, 524-535. [CrossRef] [PubMed]

66. Xu, P.; Yin, Q.; Shen, J.; Chen, L.; Yu, H.; Zhang, Z.; Li, Y. Synergistic inhibition of breast cancer metastasis by silibinin-loaded lipid nanoparticles containing TPGS. Int. J. Pharm. 2013, 454, 21-30. [CrossRef] [PubMed]

67. Gohulkumar, M.; Gurushankar, K.; Rajendra Prasad, N.; Krishnakumar, N. Enhanced cytotoxicity and apoptosis-induced anticancer effect of silibinin-loaded nanoparticles in oral carcinoma (KB) cells. Mater. Sci. Eng. C 2014, 41, 274-282. [CrossRef]

68. Sajjadiyan, S.Z.; Ghadernejad, H.; Milani, A.T.; Mohammadian, M.; Abdolahpour, S.; Taslimi, S.; Moradi-Sardareh, H.; Afrisham, R.; Kooti, W. Preparation of silibinin loaded pegylatedniosomal nanoparticles and investigation of its effect on MCF-10A human breast cancer cell line. Der Pharm. Lett. 2016, 8, 70-75. 
69. Sahibzada, M.U.K.; Sadiq, A.; Khan, S.; Faidah, H.S.; Ullah, N.; Khurram, M.; Amin, M.U.; Haseeb, A. Fabrication, characterization and in vitro evaluation of silibinin nanoparticles: An attempt to enhance its oral bioavailability. Drug Des. Devel. Ther. 2017, 11, 1453-1464. [CrossRef]

70. Huo, M.; Wang, H.; Zhang, Y.; Cai, H.; Zhang, P.; Li, L.; Zhou, J.; Yin, T. Co-delivery of silybin and paclitaxel by dextran-based nanoparticles for effective anti-tumour treatment through chemotherapy sensitization and microenvironment modulation. J. Control Release 2020, 321, 198-210. [CrossRef]

71. Jiang, M.; He, K.; Qiu, T.; Sun, J.; Liu, Q.; Zhang, X.; Zheng, H. Tumour-targeted delivery of silibinin and IPI-549 synergistically inhibit breast cancer by remodeling the microenvironment. Int. J. Pharm. 2020, 581, 119239. [CrossRef]

72. Liu, Y.; Xie, X.; Hou, X.; Shen, J.; Shi, J.; Chen, H.; He, Y.; Wang, Z.; Feng, N. Functional oral nanoparticles for delivering silibinin and cryptotanshinone against breast cancer lung metastasis. J. Nanobiotechnol. 2020, 18, 83. [CrossRef] [PubMed]

73. Ding, S.; Zhang, Z.; Song, J.; Cheng, X.; Jiang, J.; Jia, X. Enhanced bioavailability of apigenin via preparation of a carbon nanopowder solid dispersion. Int. J. Nanomed. 2014, 13, 2327-2333. [CrossRef] [PubMed]

74. Das, S.; Das, J.; Samadder, A.; Paul, A.; Khuda-Bukhsh, A.R. Efficacy of PLGA-loaded apigenin nanoparticles in Benzo[a]pyrene and ultraviolet-B induced skin cancer of mice: Mitochondria mediated apoptotic signalling cascades. Food Chem. Toxicol. 2013, 62, 670-680. [CrossRef]

75. Bhattacharya, S.; Mondal, L.; Mukherjee, B.; Dutta, L.; Ehsan, I.; Debnath, M.C.; Gaonkar, R.H.; Pal, M.M.; Majumdar, S. Apigenin loaded nanoparticle delayed development of hepatocellular carcinoma in rats. Nanomed. 2018, 14, 1905-1917. [CrossRef]

76. Huang, Y.; Zhao, X.; Zu, Y.; Wang, L.; Deng, Y.; Wu, M.; Wang, H. Enhanced Solubility and Bioavailability of Apigenin via Preparation of Solid Dispersions of Mesoporous Silica Nanoparticles. Iran. J. Pharm. Res. 2019, 18, 168-182.

77. Salehi, B.; Fokou, P.; Sharifi-Rad, M.; Zucca, P.; Pezzani, R.; Martins, N.; Sharifi-Rad, J. The Therapeutic Potential of Naringenin: A Review of Clinical Trials. Pharmaceuticals 2019, 12, 11. [CrossRef] [PubMed]

78. Fuster, M.G.; Carissimi, G.; Montalbán, M.G.; Víllora, G. Improving Anticancer Therapy with Naringenin-Loaded Silk Fibroin Nanoparticles. Nanomaterials 2020, 10, 718. [CrossRef] [PubMed]

79. Krishnakumar, N.; Sulfikkarali, N.K.; Manoharan, S.; Venkatachalam, P. Raman spectroscopic investigation of the chemopreventive response of naringenin and its nanoparticles in DMBA-induced oral carcinogenesis. Spectrochim. Acta A Mol. Biomol. Spectrosc. 2013, 115, 648-653. [CrossRef] [PubMed]

80. Kumar, S.P.; Birundha, K.; Kaveri, K.; Devi, K.T.R. Antioxidant studies of chitosan nanoparticles containing naringenin and their cytotoxicity effects in lung cancer cells. Int. J. Biol. Macromol. 2015, 78, 87-95. [CrossRef]

81. Chaurasia, S.; Patel, R.R.; Vure, P.; Mishra, B. Oral naringenin nanocarriers: Fabrication, optimization, pharmacokinetic and chemotherapeutic efficacy assessments. Nanomedicine 2017, 12, 1243-1260. [CrossRef] [PubMed]

82. Sulfikkarali, N.; Krishnakumar, N.; Manoharan, S.; Nirmal, R.M. Chemopreventive Efficacy of Naringenin-Loaded Nanoparticles in 7,12-dimethylbenz(a)anthracene Induced Experimental Oral Carcinogenesis. Pathol. Oncol. Res. 2013, 19, 287-296. [CrossRef] [PubMed]

83. Chaurasia, S.; Patel, R.R.; Vure, P.; Mishra, B. Potential of Cationic-Polymeric Nanoparticles for Oral Delivery of Naringenin: In Vitro and In Vivo Investigations. J. Pharm. Sci. 2018, 107, 706-716. [CrossRef] [PubMed]

84. Imran, M.; Rauf, A.; Abu-Izneid, T.; Nadeem, M.; Shariati, M.A.; Khan, I.A.; Imran, A.; Orhan, I.E.; Rizwan, M.; Atif, M.; et al. Luteolin, a flavonoid, as an anticancer agent: A review. Biomed. Pharmacother. 2019, 112, 108612. [CrossRef] [PubMed]

85. Lin, Y.; Shi, R.; Wang, X.; Shen, H.-M. Luteolin, a Flavonoid with Potential for Cancer Prevention and Therapy. Curr. Cancer Drug Targets 2008, 8, 634-646. [CrossRef] [PubMed]

86. Majumdar, D.; Jung, K.-H.; Zhang, H.; Nannapaneni, S.; Wang, X.; Amin, A.R.M.R.; Chen, Z.; Chen, Z.; Shin, D.M. Luteolin Nanoparticle in Chemoprevention: In Vitro and In Vivo Anticancer Activity. Cancer Prev. Res. 2014, 7, 65-73. [CrossRef] [PubMed]

87. Wozniak, A.; Napierala, M.; Golasik, M.; Herman, M.; Walas, S.; Piekoszewski, W.; Szyfter, W.; Szyfter, K.; Golusinski, W.; Baralkiewicz, D.; et al. Metal concentrations in hair of patients with various head and neck cancers as a diagnostic aid. Biometals 2016, 29, 81-93. [CrossRef] 
88. Szyfter, K.; Napierala, M.; Florek, E.; Braakhuis, B.; Takes, R.P.; Rodrigo, J.P.; Rinaldo, A.; Silver, C.E.; Ferlito, A. Molecular and health effects in the upper respiratory tract associated with tobacco smoking other than cigarettes. Int. J. Cancer 2019, 144, 2635-2643. [CrossRef]

89. Golasik, M.; Jawień, W.; Przybyłowicz, A.; Szyfter, W.; Herman, M.; Golusiński, W.; Florek, E.; Piekoszewski, W. Classification models based on the level of metals in hair and nails of laryngeal cancer patients: Diagnosis support or rather speculation? Metallomics 2015, 7, 455-465. [CrossRef]

90. Wu, C.; Xu, Q.; Chen, X.; Liu, J. Delivery luteolin with folacin-modified nanoparticle for glioma therapy. Int. J. Nanomed. 2019, 14, 7515-7531. [CrossRef]

91. Alshehri, S.; Imam, S.S.; Altamimi, M.A.; Hussain, A.; Shakeel, F.; Elzayat, E.; Mohsin, K.; Ibrahim, M.; Alanazi, F. Enhanced Dissolution of Luteolin by Solid Dispersion Prepared by Different Methods: Physicochemical Characterization and Antioxidant Activity. ACS Omega 2020, 5, 6461-6471. [CrossRef] [PubMed]

92. Chen, A.Y.; Chen, Y.C. A review of the dietary flavonoid, kaempferol on human health and cancer chemoprevention. Food Chem. 2013, 138, 2099-2107. [CrossRef] [PubMed]

93. Luo, H.; Jiang, B.; Li, B.; Li, Z.; Jiang, B.H.; Chen, Y.C. Kaempferol nanoparticles achieve strong and selective inhibition of ovarian cancer cell viability. Int. J. Nanomed. 2012, 7, 3951-3959. [CrossRef]

94. Tu, L.Y.; Bai, H.H.; Cai, J.Y.; Deng, S.P. The mechanism of kaempferol induced apoptosis and inhibited proliferation in human cervical cancer SiHa cell: From macro to nano: Anticancer effect of kaempferol on SiHa cells. Scanning 2016, 38, 644-653. [CrossRef] [PubMed]

95. Colombo, M.; Figueiró, F.; de Fraga Dias, A.; Teixeira, H.F.; Battastini, A.M.O.; Koester, L.S. Kaempferol-loaded mucoadhesive nanoemulsion for intranasal administration reduces glioma growth in vitro. Int. J. Pharm. 2018, 543, 214-223. [CrossRef]

96. Govindaraju, S.; Roshini, A.; Lee, M.; Yun, K. Kaempferol conjugated gold nanoclusters enabled efficient for anticancer therapeutics to A549 lung cancer cells. Int. J. Nanomed. 2019, 14, 5147-5157. [CrossRef]

97. Khan, N.; Syed, D.N.; Ahmad, N.; Mukhtar, H. Fisetin: A Dietary Antioxidant for Health Promotion. Antioxid Redox Signal 2013, 19, 151-162. [CrossRef]

98. Ghosh, P.; Singha Roy, A.; Chaudhury, S.; Jana, S.K.; Chaudhury, K.; Dasgupta, S. Preparation of albumin based nanoparticles for delivery of fisetin and evaluation of its cytotoxic activity. Int. J. Biol. Macromol. 2016, 86, 408-417. [CrossRef]

99. Feng, C.; Yuan, X.; Chu, K.; Zhang, H.; Ji, W.; Rui, M. Preparation and optimization of poly (lactic acid) nanoparticles loaded with fisetin to improve anti-cancer therapy. Int. J. Biol. Macromol. 2019, 125, 700-710. [CrossRef]

100. Subramaniam, S.; Selvaduray, K.R.; Radhakrishnan, A.K. Bioactive Compounds: Natural Defense against Cancer? Biomolecules 2019, 9, 758. [CrossRef]

101. Gaber, D.M.; Nafee, N.; Abdallah, O.Y. Myricetin solid lipid nanoparticles: Stability assurance from system preparation to site of action. Eur. J. Pharm. Sci. 2017, 109, 569-580. [CrossRef] [PubMed]

102. Khorsandi, L.; Mansouri, E.; Rashno, M.; Karami, M.A.; Ashtari, A. Myricetin Loaded Solid Lipid Nanoparticles Upregulate MLKL and RIPK3 in Human Lung Adenocarcinoma. Int. J. Pept. Res. Ther. 2020, 26, 899-910. [CrossRef]

(C) 2020 by the authors. Licensee MDPI, Basel, Switzerland. This article is an open access article distributed under the terms and conditions of the Creative Commons Attribution (CC BY) license (http://creativecommons.org/licenses/by/4.0/). 